\title{
India's Democratic Identity and Its Policy towards Myanmar from 1988 to 2010
}

\author{
Htwe Hteik Tin Lwin, Tsukuba University, Japan
}

\begin{abstract}
Since the 1990s, India has reengaged with Myanmar government. The Indian government's engagement with Myanmar's military junta provoked a controversial issue in international community, claiming that 'the oldest democratic country in Asia' is not doing enough to promote democracy in her neighborhood. The question raised was what has motivated India to develop cordial relations with Myanmar's military junta. The paper emphasizes the role of India's democratic identity in Indo-Myanmar policy during 1988-2010. Previous literatures revealed India's policy towards Myanmar in economic and security assumptions. They tended to sketch India Policy as 'in-active' in promotion of democracy practiced from west democratic institutions norms, such as 'isolation' and 'totally disengagement'. The paper briefly explains Indo-Myanmar relations from 1988 to 2010. Security and economic interests play a larger role than the intention to promote democratic identity in Myanmar. The paper argues that in the background of Indo-Myanmar development cooperation, India has made efforts to promote democratic value in Myanmar differently from other western democratic countries. Engagement policy has shaped Indo-Myanmar relations in the 1990s. India 'engagement policy', 'non-isolation' and 'development cooperation' with Myanmar government has brought up contractions.
\end{abstract}

Keywords: Democracy, Military Junta, Democratic Identity, NLD

\section{Introduction}

India-Myanmar relations faced several ups and downs during 1988 and 2010. Both countries regained their independent from Britain in 1947 and 1948 respectively. Newly democratic states enjoyed friendly relations. India and Myanmar were active founders of Non-Alignment Movement (NAM). On 2 March 1962, General Ne Win overthrew the Democratic Government and seized power. He formed Burma People's Socialist Party
(BPSP). Coup d'état by General Ne Win from 1962 to 1988, Indo-Myanmar relations were 'strained'. The relations were further strained in 1988 when the military oppressed pro-democracy movements. On 18 September 1988 military formed State Law and Order Restoration Council (SLORC) and replaced the role of BPSP. In August 1988 democracy uprising movements, known as '8-8-88', Indian Embassy in Rangoon actively participated by financing pro-democracy activists and 
offering shelters to students and refugees in New Delhi and Indo-Burma border. New Delhi strongly voiced for restoration of democracy in Burma and demanded the military government to recognize the 1990 parliamentary election results where prodemocracy leader Aung San Su Kyi's National League for Democracy (NLD) party won 392 out of 492 contested seats. SLORC refused to recognize the election result of 1990 and placed the leader of NLD, Aung San Su Kyi under house arrest and the party was suppressed. India strongly supported NLD and pro-democracy movements of students and refugees on Indian land.

However, the support for democracy was dimed when India was keen to link economic cooperation with Southeast Asia and East Asia countries. Look East PolicyLEP forced India to explore both regionally and globally for promotion of its economic interests. Myanmar's location at the trijunction of Southeast Asia, West Asia and East Asia creates security and economic imperatives for India. The reports of China growing presence in and around Indian Ocean and its technical assistance in upgrading infrastructure in the Coco Island ${ }^{1}$ raised security concern for India.

Another security concern is to eradicate northeast insurgent groups in India where the groups have their bases at $1643 \mathrm{~km}$ long Indo-Myanmar borders. In addition to this, India's booming economy and industrialization are driving India's energy demand higher. Gas discoveries in the Bay of Bengal have attracted India to invest a share of the gas in Myanmar.

The question of Indian's value on democracy came up for debate when many Generals in Myanmar Junta visited India. India faced severe criticism from

\footnotetext{
${ }^{1}$ Coco Island is in the Bay of Bengal, some $300 \mathrm{kms}$ south of mainland Myanmar .The Islands is administered by Myanmar, Yangon Region.
}

international community for its reengagement with the military government. India accelerated its relations with Myanmar government by providing aid and development projects such as implementing road, railway, ports, upgrading infrastructures, funding power projects and establishing human resources tanning centers. India's posture brings debatable argument that development cooperation and engagement with the military ruled neighbor foster democracy or not. Some Western countries considered that long term approach policy only spoil the chances and delay for early progress. India's engagement policy also provoked controversial domestic debate to question Indian's stance on democracy.

The paper argues that India's reengagement with Myanmar's Military junta is not only economic and security assumptions but the engagement also manifests India's democratic identity. India's engagement policy with Myanmar is also a manifestation of India's democratic identity. The actions and policy of India towards Myanmar seemed to be pursuant to material forces but the forces can be regarded as a democratic identity. IndoMyanmar relations are not shaped only by power, interest or identity but by combination of them. Indo-Myanmar relations need to weigh the causal importance of different types of factors, for example, material and ideal, international and domestic.

India had a sharp tone towards Myanmar for oppressing pro-democratic movements from 1988 to 1990. But since 1990s, India had reversed its policy and started engaging with Myanmar government. Scholars had analyzed IndoMyanmar relations under the separate lens of Realism, Liberalism and Constructivism. Compelling analyses of empirical puzzles of Indo-Myanmar relations can be built through combining realist, liberal and 
constructivist modes of explanation, analytical eclecticism. Eclectic theorizing helps us understand complex social and political process of Indo-Myanmar relations.

Realists argue that to achieve survival, states increases power. On the other hand, liberal believes in decline in conflicts among states via transnational and increase in economic interdependence of the world. The multinational corporations and economic interdependence can produce cooperative arrangement and a rational aggregation of social preferences. Realism and liberalism together, for instance, can generate powerful intuitions into the blend of interest and interdependent. IndoMyanmar policy also reflects a mixture of realist and liberal elements. India since the 1990s has consistently sought to engage Myanmar economically and militarily. India looks out for way to maximize its economic interest to counter growing Chinese economic expansion in Myanmar.

India's growing interest on Myanmar is also driven by the finding offshore gas fields at western costal line of Myanmar. The move involves an element of maximizing economic power as India seeks to constrain Chinese influence in Myanmar, through economic cooperation. The rise of China in Asia began a change in the IndoMyanmar relations in line with realist expectations. From India's perspectives, countering Chinese in Myanmar is possible only through a close engagement with Myanmar.

In this realist-liberal perspective, India remains economically fully engaged in Myanmar. India's diplomacy aims at a slow, steady and prolonged process of encouraging Myanmar to contribute more to economic development. Singing of IndoMyanmar Border Trade Agreement between the two countries on January 21, 1994, for example, was inspired by the belief that the likelihood of conflict between states would be reduced by creating common interest in trade and economic collaborations among members of the same geographical regions. In addition to this, Look East Policy of India-LEP's aim is to get closer link with booming economy of Southeast Asia countries. In this regard, New Delhi perceives Myanmar as a vital land-bridge for India's connection with Southeast Asia Countries.

A combination of realists and constructivists' point of view also offers insight into Indo-Myanmar relations. The unstable issue of Indian insurgents, a serious trouble spot in India's northeast region, illustrates the realist-constructivist analytical possibility. India is eager to eradicate northeast insurgent groups with the help of Myanmar military. Indian government takes a pragmatic approach. It views military cooperation can exchange information, enhances official talks and helps to build trust. Indo-Myanmar's joint military cooperation (called Golden Bird) to counter insurgent groups in northeast of India leads to political contacts, facilitates trust between government, distributes power and enhances shared interests.

India's weapon sales do not only involve weapons and cash but also include personal ties and a web of connections among military officials. The move corroborates constructivist insight. It promotes the creation of a network of transgovernmental tie at military personnel level. In fact, military cooperation can do good transnational tie between two governments. While western democracies pursued a policy of isolation, India sought to build bridges instead of fence. For instance, Myanmar's membership at Bay of Bengal Initiative for Multi-sectoral and Technical and Economic Cooperation (BIMSTEC) and Mekong Ganga Cooperation (MGC) enhanced Indo-Myanmar's ties. The sub/regional organizations bring two countries closer to pursuit common 
prosperity via the use of mechanism of sub/regional economic integration.

\section{Diagram 1 Possibilities of Eclecticism in India-Myanmar Relations}

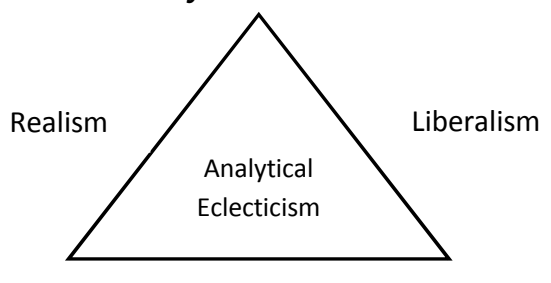

Constructivism

Source: J.J. Suh, Peter J. Katzenstein and Allen Carlson, 2004 p.9

The first section of the paper discloses deflect in trade relations and democratic identity. The next section deals with Indian Policy to expedite reform process in Myanmar. Even under severe criticism from western countries, India continued to engage with Myanmar government. Like many other countries, India, too, seems to use development aid to win-over recipients' people and influence its government. Indian approach was starkly different from some others international donor institutions. For example, India's development projects emphasized more on capacity building, media development and uplift of education as well as establishment of human resources development centers. This part looks into the works of India's development cooperation in Myanmar.

\section{A lost in Trade Relations}

Compared to India's trade with China \& Thailand, India's trade with Myanmar lagged far behind. The trade gap among countries is noticed as follow:
Table 1 Myanmar's Trade with Neighboring Countries: Exports and Imports 1995-2003

\begin{tabular}{|c|c|c|c|}
\hline & 1995 & 2000 & 2003 \\
\hline & \multicolumn{3}{|l|}{ Export } \\
\hline China & $11.3 \%$ & $6.4 \%$ & $6.2 \%$ \\
\hline Thailand & $16.9 \%$ & $13.3 \%$ & $33.0 \%$ \\
\hline \multirow[t]{2}{*}{ India } & $12.3 \%$ & $9.4 \%$ & $12.9 \%$ \\
\hline & Import & & \\
\hline China & $25.0 \%$ & $19.5 \%$ & $33.3 \%$ \\
\hline Thailand & $14.2 \%$ & $19.8 \%$ & $16.1 \%$ \\
\hline India & $1.2 \%$ & $2.1 \%$ & $3.2 \%$ \\
\hline
\end{tabular}

Table 2 FDI to Myanmar by Country (as of March 2002)

\begin{tabular}{|c|c|c|c|}
\hline & $\begin{array}{c}\text { Amou } \\
\text { nt }\end{array}$ & $\begin{array}{c}\text { Shar } \\
\text { e } \\
(\%)\end{array}$ & $\begin{array}{c}\text { No. of } \\
\text { Enterpris } \\
\text { es }\end{array}$ \\
\hline Singapore & 15.7 & 20.1 & 71 \\
\hline UK & 14.0 & 18.9 & 37 \\
\hline Thailand & 12.9 & 17.5 & 49 \\
\hline Malaysia & 6.0 & 8.1 & 28 \\
\hline USA & 5.8 & 7.8 & 16 \\
\hline France & 4.7 & 6.3 & 3 \\
\hline Indonesia & 2.4 & 3.2 & 12 \\
\hline $\begin{array}{c}\text { The } \\
\text { Netherlan } \\
\text { ds }\end{array}$ & 2.4 & 3.2 & 5 \\
\hline Japan & 2.1 & 3.2 & 23 \\
\hline Korea & 2.1 & 3.1 & 32 \\
\hline
\end{tabular}

Source: Toshihiro Kudo and Fumiharu Miedo 2002)

The above study revealed reverse assumptions of economic policy being the vital factor in India's Myanmar policy. The Indo-Myanmar trade remained insignificant 
only amounting to few profit per year. Additionally, the traded items between India and Myanmar were mostly third country products and there was no concerted effort on the part of the government to develop the border regions and expand the tradable items. Trade between Myanmar and China was immense and with China, trade volume increased continually per years during 1988 to 2000 .

\section{Table 3 Total Trade between China and} Myanmar

\begin{tabular}{|l|l|}
\hline Year & $\begin{array}{l}\text { Total Trade Volume in } \\
\text { US dollar (million) }\end{array}$ \\
\hline 1988 & 9.5 million \\
\hline 1989 & 76.03 million \\
\hline 1995 & 767.40 million \\
\hline 1998 & 576.49 million \\
\hline 2000 & 621.26 million \\
\hline & \\
\hline
\end{tabular}

Source: Poon Kim Shee 2000

India had no chance to compete with China in terms of engaging in trade relations with Myanmar. It was obvious that India had less chance to conquer the economic field already occupied by its neighbor. Although Indo-Myanmar trade relations did not work out well as expected by economic analysts, India was positively rather than negatively disposed to maintain Indo-Myanmar relations.

In the age of economic interdependence, trade approach help promote not only economic activities along Indo-Myanmar border, but also foster mutual benefits and interconnection among people. Moreover, economic activities reduce illegal trade. The more development in border region, the more stability prevails in borders. The moves corroborate liberal insights.

India's stance shifted from a policy of condemning to re-engaging with Myanmar not only to counter Chinese influence, expand economy and eradicate northeast insurgent groups with help from Myanmar military but also with a goal to restore democracy. India is surrounded by politically unstable countries and some of her neighbours export terrorists. In this regards, India advocated for restoration of democracy and rule of law in its neighbouring countries. India understood that democratic institutions in sub-continent would ensure its security.

If India had to end relations with Myanmar, she also had to suspend her relations with neighboring military ruled countries. Especially in her backyard, India had maintained relations with military ruled country, Bangladesh and Pakistan. According to the Failed State Index (2005), India was surrounded by the list of failed states. Afghanistan placed the top 10 while Pakistan, Myanmar, Bangladesh, Sri Lanka and Nepal figures in the top 30 among a list of 76 countries. India faced severe impact of terrorism due to her neighboring failed states. Serious deficits in democracy and governance in her neighborhood emphasized India to call on Myanmar government to expedite reform process.

Political stability in Myanmar matters since Myanmar's stability had significant impact on stability and development of northeast India region. Thus, Indian government, on the ground's purpose, had a strong suggestion for military government to release pro-democracy activists and urged Myanmar government to restore democracy.

Despite deficit in trade and energy sector, India, nevertheless maintained relations with Myanmar. Indian government wanted to see Myanmar to restore democracy. In order to restore democracy, India pursued pragmatic approach, so that Myanmar would be kept in close contact with democratic institution. Sanction only pushed Myanmar to stay away from international community. Close contact and engagement would bring 
Myanmar leaders to have broader outlook on democratic values. With a close contact, India persistently exhorted Myanmar government to restore democracy and release of democracy activists. In the aftermath of 2007, when the Saffron Revolution revealed that 'change' was desperately needed in Myanmar, India urged Myanmar government to speed up political reform and release of prodemocracy leader Aung San Su Kyi. India stood against sanctions on Myanmar.

During $6161^{\text {st }}$ Meeting of UNSC in 2009, some countries started reviewing to work with Myanmar government in order to support the reform process. Indian politicians assumed that isolating Myanmar government would not be the answer. Disengagement with Myanmar government was not in the interest of India. Only engagement with Myanmar would expedite reform process. Besides, Indian civil society played certain extent of role in pressuring Indian government to urge Myanmar government to restore democracy. While accessing Myanmar's market, India at the same time, called on Myanmar government to restore democracy, stability, national reconciliation and release of all prodemocracy activists.

\section{The Contribution of Democratic Identity to the Enforcement of Democracy}

India's concern over Myanmar political condition became more pronounced in the Saffron Revolution. The Saffron Revolution started on 15 August 2007 to protest against the government due to a sudden rise of petrol. Led by monks, the demonstration took the form of non-violence resistance. A leading monk of the revolution explained the reason why Buddhist monks took part in the political situation: "as a monk, we do not take up arms. The political situation in Myanmar would not be benefited using arms. I would say our protest was not successful". However, the revolution gave signal to the government that change was desperately needed. International community had called for further sanctions and urged India to intervene and facilitate a dialogue between the military rulers and pro-democracy groups. When Indian External Affairs Minister Pranab Mukherjee met his counterpart U Nyan Win at the U.N General Assembly in October 2007, the Minister urged to take forward efficiently the process of national reconciliation and political reform. India did not remain reluctant to use its voice to expedite for change in Myanmar anymore.

There were reasons India did not remain silence on the Saffron Revolution. It was noticeable and there was some evidence that India policy was shifting in the direction towards 'democracy promotion'. One noticeable evidence was Indo-US relations with regard to nuclear issue. In 2005, United Stated set up 'New Framework for US-India Defense Relations' to push the latter into a strategic alliance with Washington in order to counter China in Asia and in return, the Bush Administration had offered India to lift its 30 year nuclear sanctions and to sell advanced US nuclear technology, legitimizing India's open violation of the Nuclear Non-Proliferation Treaty. India declared to create an international environment conducive to promotion of democratic values, and to strengthen democratic practices in societies which wish to become more open and pluralistic. It was difficult to tell India's real stance in Myanmar as a 'democracy promoter' in the eyes of major global democracies. The second reason, when the UN Security Council issued a statement "strongly" deploring the Myanmar's oppression of pro-democracy demonstrators, surprisingly, the statement was not blocked by China, who vetoed a UNSC resolution on Burma in 
January 2007. Instead, China's Ambassador to the UN, Wang Guangya, said that China wished to see stability, mutual reconciliation, and progress towards democracy in Myanmar. In addition, Premier Wen Jiabao confirmed China's shift, and expressed hopes that stability, national reconciliation, and democracy to be achieved as soon as possible through peaceful means. Besides, news reported that in a meeting between Myanmar Foreign Minister U Nyan Win and Chinese State Councilor Tang Jiaxuan in September, the latter called on Myanmar to "push forward a democracy process that is appropriate for the country". India's could no longer ignore to be 'in-active democracy promoter' when authoritarian China condemned and reacted to September 2007 Saffron Revolution.

\section{Against Sanction Policy}

India shifted its policy was somehow connected with growing Sino-Myanmar military relations. According to Indian defense source interviewed by author, China provided US\$ 1 to 1.2 billion worth of weapons and China had been engaged in constructing and upgrading the road and rail network system to connect its inland province Yunnan.

Besides, Myanmar's strategic 1930 km long coastline further increases India's interest. The coastline controls the eastern arch of the Bay of Bengal which provides China the shortest sea route to South Asia. In reverse, the route also provides India's deadlock inland northeast states to Southeast Asia. India could benefit from interacting with Myanmar government and lessen the latter dependency on China for military cooperation, trade and investment.

In this context, Indian official restricted their view towards Myanmar calling on to restore democracy. On 4 November 2007,
Indian Permanent Representative at the UN Human Rights Council (HRC), Swashpawan Singh said that Aung San Su Kyi played a key role in Myanmar's emergence as a democratic country, though India did not support HRC resolution in 2007 calling for sanctions on Myanmar. He said India had advocated an outcome that was forward-looking, non-condemnatory, and sought to involve the authorities in Myanmar in a peaceful outcome. According to former ambassador to Myanmar, Indian diplomats had been urging the generals to set Aung San Su Kyi free during private meetings with them.

On the other hand, India opposed the US's call on sanction on Myanmar. On 2 October 2007, the Human Rights Council adopted by consensus on the situation of human rights in Myanmar in which it strongly condemned the use of violence against peaceful civilian demonstrators. The resolution called for civil, political rights, economic, social and cultural rights. The resolution called on Myanmar government to embark on a peaceful dialogue with prodemocracy leaders and all parties concerned. India had emphasized the importance of protection and promotion of human right through dialogue.

International community started to rethink engaging with Myanmar government. Representatives from United Nation Security Council (UNSC) expressed their concerns at $6161^{\text {st }}$ meeting held on 13 July 2009 at Security Council. During the meeting, some representatives showed sights to engage with Myanmar in order to support reform process.

Policy of sanctions applied by the Western countries had little prospect, weakening the military regime to the point of giving up power. There were disagreements among international leaders on sanction against Myanmar. International community had fallen in to two general categories, one was unambiguously called 
for a democratic transition, and the other called for engagement with the military government rather than isolation. For India, India not only shares $1640 \mathrm{~km}$ border and sea boundary with Myanmar in the Bay of Bengal but also shares culture and religion ties. Pursuing dialogue and diplomatic engagement with Military regime rather than isolation was the effective way to convince Myanmar government to improve human rights and political situation. The sanctions only pushed Myanmar far from democratic institutions. India felt that the way to change in Myanmar was not practicing isolation strategy.

Despite criticism from international community for India's engagement with Myanmar, India seemed to wait tolerantly for the development of the "Road Map to Democracy". Giving too much pressure on human right and democracy in Myanmar would not work out. While India busy engaging with Myanmar government, US and western countries emphasized on sanctions.

\section{Sub/Regional Institutions and Transnational Ties}

Energy rich Myanmar helps India fulfills its energy strive. In a world of scarce resources nowadays, states compete with each other for their shares. Individual competition in civil society and market capitalism best promotes the welfare of all by most efficiently allocating scarce resources within society. India sought to increase its regional power, expand partnership with the West and created an international rule of the system which were conducive to profile India as 'democracy promoter'. The moves made by India to welcome Myanmar into sub/regional economic institutions and competition to secure its share of economy corroborate the view of neoliberals.
Neoliberals assume that there is an interest to serve, therefore there is an institution. New Delhi regarded that it was better to engage than to isolate Myanmar.In line with the UN Human Rights Commission's decision to enhance the role of regional and sub-regional in the promoting and consolidating of democracy, India welcomed admission of Myanmar into sub/regional economic organizations, for example, Bay of Bengal Initiative for Multi- BIMSTEC in 1997 and MGC in 2000. The $55^{\text {th }}$ meeting of UN Human Rights Commission encouraged 'regional and cross-regional organizations and arrangements' to initiate partnerships to assist in disseminating knowledge about the role of democratic institutions and systems 'in facing the political, economic, social and cultural challenges in their respective societies'. Myanmar's admission in sub/regional economic organizations would further broaden the mind sets of military regime. In this regard, India had a lead role, where big power countries located far from Myanmar were not able to do so. Sub/regional level constantly promotes and consolidates democracy and wider political involvement; trade facilitation and pluralism increase the possibilities of a change towards democracy. Not only engagement with Myanmar helped to stabilize insurgency and development of its Northeast India region but a vast network of transnational and trans-governmental ties at various levels further bound networks of Indian and Myanmar governmental levels.

An assessment of India's interests in Myanmar suggests that Myanmar's geostrategic location attracts India. For example, in 2009, South East Asian Analysis Group scholar, Subhash Kapila commented on his paper with a title of Myanmar strategic imperative effectiveness. His paper analyzed United States' policy of sanction and India's policy of engagement with the 
military regime in the early 1991 . Under the sub-title of United States could use India as a Bridge to Politically Reach Out to Myanmar, Kapila argued that 'Myanmar is a strategic imperative not only for US security but overall Asian security interest too'. Indian officials were wary of the result of South Asian Association for Regional Cooperation (SAARC) and they shifted their focuses on ASEAN as ASEAN has become among the successful regional associations. Indian became a member of ASEAN's other regionwide institutions such as the ASEAN Regional Forum (ARF), the Asia-Pacific Economic Cooperation (APEC) and the Asia-Europe Meeting (ASEAM).

India set trade target of US $\$ 50$ billion with ASEAN by 2010. India also focused to provide basic drugs at low cost and a target of 1 million tourists to India from ASEAN region. India entered India-ASEAN free Trade Agreement on 13 August 2009 with the aim of US\$ 10 billion trade in the first year. India became a member of ARF in 1996. Myanmar as the only ASEAN country which shares a land and also a maritime boundary with India, become a gateway to ASEAN. On the other hand, the difference becomes clear if we think of Myanmar's membership in sub/regional institutions. The membership creates a sense of 'regionalism'. Regionalism, in the sense of the sentiment or consciousness of a common identity, is culturally or politically constructed. The presence of shared interests suggests that processes of cooperation and interdependence are likely to share common identities among member countries.

\section{India's Development Cooperation}

India regards a philosophy that enhancing development cooperation is an attempt to introduce 'something more concrete' democratic government in
Myanmar. Unlike Organization for Economic Cooperation and Development (OECD) countries, India does not have concrete policy for development cooperation. In recent years Indian involvement of development projects in Myanmar became noticeable.

Since 2000 India has been playing a role in development projects in Myanmar. India's development policy approach in Myanmar is a bit distinct from neighboring countries. It is widely believed that the political and developmental approaches can be compared along several dimensions. Political approach sees democratization as a process of political struggle in which political actors who can be clearly identified as democrats content with nondemocratic forces while developmental approach conceives democratization as a slow, iterative process measured in decades and marked by the gradual accumulation of grains. The developmental approach was dominant in India policy towards Myanmar. This dominance manifests itself in the following India's democratic identities:

a) A focus on human resources development work, especially capacity building for state institutions;

b) An emphasis, within civil society programming, on grass-root level activities and other developmental projects;

c) A linkage of democracy work providing training to civil and military officials;

d) To stress the concept of partnership even with authoritarian regimes.

Christian Wagner distinguishes between support of democratic development or the participation in economic sanction and economic and bilateral development cooperation. She stresses that Indian democratic identity largely prefers the 
economic and bilateral development cooperation.

Indian Ministry of External Affairs (MEA) considers itself to be focal Ministry for India's development assistance. MEA has various institutional programme under India Development Cooperation (IDC), such as the Indian Technical and Economic Cooperation (ITEC) programme, Aid to African countries through Special Commonwealth Assistance Programme and Bilateral Aid to neighboring and other developing countries. India did not publicly admit that they were 'promoting democracy' but background of development cooperation, India tried to strengthen certain element of democratic identities

Knowing that education is the window to democracy, India, therefore, had been participating in education development since 2000. India provided laboratory equipments worth 500,000 US Dollars to Yangon University aiming to enhance scientific research activities and it also provided funds for establishment of a business training institute, entrepreneurship Developmental Center, banking, small and medium sized enterprise and English language training courses. India supplied academic and educational needs such as exchange of research materials, publications and information, organizing of joint conferences and seminars, organizing of joint research programmes, arranging of joint training and retraining programmes, setting up sandwich progarmmes for $\mathrm{PhD}$ students, exchange of academic and administrative staff, exchange of scholars and students and exchange of collaboration of technology.

One of the obvious Indian contributions in education sector is granting of 2 million US Dollars to build the India-Myanmar Centre for Enhancement of IT skills centre in Yangon. India's contribution in educational development project has helped
Myanmar students to gain broader knowledge because Myanmar needs more investment in education sector.

The army cooperation between Indian Army and Myanmar started in 1995. Joint military counter insurgency operations had already taken place. Joint counter insurgency operation was undertaken in order to stabilize and develop northeast region. Stability is needed because India regards Northeast state as the centre of a thriving and integrated economic space, an opportunity to integrate not only with Indian mainland economy but also with India's neighboring countries.

In addition to joint military cooperation, India also supported the capacity building of defense officials of Myanmar. India provided training to mid-level army officials. Military training provides mechanism between countries to foster cooperation. Defense industries involved in coproduction arrangement have formed joint committees, annual conferences all of which facilitate the development of personal ties and social networks among armies.

Military cooperation involves not only exchange of equipment and money but also generate interconnection among army officials. In this context, Indian provided scholarship to Myanmar military officers at the Indian National Defense College (NDC) in New Delhi, which is considered one of the highest ranked defense institutes imparting comprehensive forms of training for both defense and civilian officials. Indian side offered courses to defense officials who are between the ages of 40 to 50 and regarded as potential leaders in the military. These mid-rank military officials are provided with fully support of living allowance provided with housing facilities in New Delhi. The course offers broader outlook towards various issues ranging from social to global issues. The course focuses on Social political study, Economy, 
Science and Technology study, International Security Environment, Study on Global Issues, India's Strategic Neighborhood, Strategies and Structure for National Security. National Defense Colleague has been the vocal advocates for a democratic transition, showcasing democracy in practice through the syllabuses offered by NDC. Interestingly NDC syllabus not only focuses on national security aspect but also on boarder out look towards socio-political aspects of domestic influence, economic development, environment, strategic neighborhood and multilateralism.

The course content of National Defense Colleague of India is different from the course content of National Defense University of Pakistan which also offers training to Myanmar military officials. While the latter focuses on national security and war course, the syllabus of NDC highlights the essential role in cooperation and understanding between defense and civil officials. This is important as in military ruled countries where there is lack of cooperation among military officers and civil officials. David Steinberg at Georgetown University believes that that the most likely source of political evolution in Myanmar would come from internal dynamics. Since the 2000s India has emphasized more on 'capacity building' of the government staffs in Myanmar.

India's assistance on institution buildings belong to capacity building approach. Sponsoring training of young diplomats, mid-senior military officials and young journalists fall under the category of knowledge sharing approach. The courses offered by National Defence College (NDC), Foreign Service Institute (FSI) and Institute of Mass Communication explicitly focus on information transparency, human rights, Indian political system and multilateralism. Myanmar ranked at the bottom for good governance among nineteen Asian countries. Good governance term has become widely used in development literature. According to United Nations Social and Social Commission for Asia and Pacific good governance has eight major characteristics; accountable, transparent, responsive, effective and efficient, equitable and inclusive and follows the rule of law. Myanmar, for example, lacked information transparency.

Decades of dialogue by the Indian diplomats and determined engagements despite disagreement and non-support in international community finally enable India to inculcate a certain trust in Myanmar government. For instance, Myanmar accepted MEA's offer for special course on Myanmar diplomats at FSI and mid-level military official training course at NDC. Academic cooperation between IndoMyanmar Working Group was initiated by Indian government for Scientific and Technology cooperation in which India agreed to train Myanmar scientists and supports the visit of Indian technicians to Myanmar. Academic collaboration also took place in the areas of medical instrumentation, aquaculture \& biotechnology, metrology, standards and quality certification and non-conventional sources of Energy.

In the initial years after the launch of LEP, India had given more weight on economic imperative than trainings or setting up knowledge-based institutions in Myanmar. India had explicitly highlighted economic and security interests as major foreign policy for Indo-Myanmar relations in the first 2000s. The first Indo-Myanmar border trade agreement signed 21 January 1994, for example, showed India's eagerness to open more border check points so that India could increase in border trade that led to cut down the illegal trade and closely monitor the activities of insurgent groups in northeast of India. 
But India did not get their profit target as previous section stated. However, starting from 2000, India has given more emphasis in the field of human resources development and capacity building in order to support gradual and inclusive political change in the country. India had involved itself with capacity building by sponsoring trainings for civil servants, military officials and civil society.

Trainings courses both in India and Myanmar not only refers to development as a foundations for a country's reformation system but also promotes rule of laws, governance, public administration, legitimacy, democratic system, human rights, government officials participation in decision making process and information transparency. Whenever India had the opportunities to talk to Myanmar government leaders, India had spoken about the need for reconciliation, for peaceful change.

Gradual implementation of India's contribution in infrastructure and noninfrastructure was the Indian way of approaching to get close in touch with military regime. Efforts to gain trust of Myanmar government did not work out over night for India. India invested in long term engagement and penetrated to gain trust from military leaders and persistently urged to release democratic leader Aung San Su Kyi and the need to look forward to national reconciliation. The imperatives of idealism and democratic identity have not completely disappeared at Indo-Myanmar relations. India did not anymore voiced on 'noisy democracy'; instead it approached, penetrated and built in the trust with Myanmar ruling government.

India's development cooperation was actively involved in several projects both in infrastructure and non-infrastructure. India had been providing its development assistance in Myanmar in the form of financial and technical assistance. Financial assistance was provided as grants, concessional lines of Credit-LoC by the Exim bank and Joint venture assistance. India enhanced 'constructive engagement' with Myanmar government since General Maung Aye's visit in November 2000. The visit ended up singing several development projects, particularly cooperation in the field of science and technology and human resource development. Development cooperation was the effective way of engaging with the military regime since most nations embargoed development aid in Myanmar.

Though India's financial assistance to Myanmar only ranked five among eight countries at 4.89 million US\$ in 2005-2006, 8.89 million in 2006-2007 and 4.44 million in 2007-2008, India's contribution more or less had some effects on the general public. For example, India was interested to implement infrastructure of railways and roadways in order to develop welfare of the peoples living in the border areas. A noticeable connectivity provided by India was upgrading of India-Myanmar Friendship Road, a 160 km long road linking northeastern state of India and northwestern part of Myanmar.

One might argue that India's project India-Myanmar Friendship Road built entirely by the Indian Army's Border Roads Organization at a cost of US\$30 million was to extend India's economic interest. India regarded building and implementing of 165 km long India-Myanmar Friendship Road which connects Tamu city in Northeast of India and Kalaymyo ${ }^{2}$ city in Myanmar was to enhance connectivity between the people and the equipment would be utilized in development of rural areas in Myanmar.

The stability of northeast India is essential since northeastern provides a bridge between the rest of India and

${ }^{2}$ It is situated in Saigaing district, north-west part of Myanmar. 
Southeast Asia. This region plays constructive role in fostering peace and stability. In order to promote peace, stability and social welfare of border area, for example, one of the events done by India government with Myanmar authority was that they conducted mega medical camp along Indo-Myanmar border in 2010.

Locals' people on both sides benefited from the services of the general physicians, specialist doctors, dentist and veterinary doctors of the Indian Army. The moves of enhancing socio welfare of border people implied that India was eager to strengthen peace, stability and harmony in border areas. Once border is stable, then there would be economic development. Delay in economic development lead to instability in the border region, thus, sparking fuel to insurgent groups.

India assistance in infrastructure development projects during 2001 to 2010 totaled about US\$550 million. In line with the LEP, connectivity and development cooperation become key word for facilitating Indo-Myanmar relations. India's development cooperation in Myanmar over the past two decades was in low profile as compared to Chinese's development cooperation.

When India extended her relations with Myanmar government in 1990, there was infrastructure and road construction projects only at two countries' border areas. Then, India had further strengthened into wider development cooperation. Several among them, Kaladan River project were prominent as people from both sides would benefits their socio-economic lives.

\section{Human Resource Development (HRD) Cooperation}

Despite harsh criticisms from democratic countries for approaching Myanmar differently from the West and its normative beliefs, India had committed to an active involvement in the field of Human Resource Development-HRD particularly education, science and information technology and development of media.

Human Resources Development assistance was given to Myanmar civil society organizations by India so that Myanmar people could expand activities. For example, capacity building, human empowerment, trainings, and other development cooperation helped widen perspectives of Myanmar civil servants and professionals. Change comes from human empowering.

Engaging in broader range of civil society could generate more ideas and consensus on how to expedite or persuade or initiate reform process. Thus, interaction between India and Myanmar could bring necessary and possible change. The endeavor to foster democratic identity in her neighbors matters because India's neighborhood replete with authoritarianism. Indian neighbor China had enhanced its relations in South Asia countries, for example, with Sri Lanka's Rajapaksa regime and the Pakistani Army. The China's best friends threaten Indian societies and domestic instability. India eastern neighbor Myanmar had cemented its military ties with China since 1988. 
Table 4 Indian Contribution in Infrastructure Development Some Major Indian infrastructural projects in Myanmar

\begin{tabular}{|c|c|c|c|}
\hline No. & Project / Name & $\begin{array}{l}\text { Contribution } \\
\text { US\$ million }\end{array}$ & Year \\
\hline 1. & $\begin{array}{l}\text { Tamu - Kalewa Road and } \\
\text { constructionand upgrading of the Rhi- } \\
\text { Tiddim and Rhi-Falam Road }\end{array}$ & - & 2001 \\
\hline 2. & $\begin{array}{l}\text { Up gradation of Yangon-Mandalay } \\
\text { railway link }\end{array}$ & 56.35 & 2003 \\
\hline 3. & Two Telecom Project & 7 & 2004 \\
\hline 4. & $\begin{array}{l}\text { Tamanthi Hydro Electric Power highway } \\
\text { project }\end{array}$ & 56 & 2004 \\
\hline 5. & Revamping of the Thanlyin refinery & 20 & 2004 \\
\hline 6. & IT related project & 3 & 2004 \\
\hline 7. & $\begin{array}{l}\text { To upgrade remote sensing ground } \\
\text { receiving station in Yangon }\end{array}$ & 1.3 & 2006 \\
\hline 8. & $\begin{array}{l}\text { For assistance with delineation of } \\
\text { Myanmar's continental shelf }\end{array}$ & 3 & 2006 \\
\hline 9. & $\begin{array}{l}\text { Kaladan Multi-Modal Transport } \\
\text { Project }\end{array}$ & 10 & 2006 \\
\hline 10. & Direct Telephone Communication & 7 & 2006 \\
\hline 11. & Heavy Duty Water Pumps & 20 & 2006 \\
\hline 12. & Thathay Chaung Hydro power project & 60 & 2007 \\
\hline 13. & $\begin{array}{l}\text { Credit line for an aluminum conductor } \\
\text { steel reinforced wire manufacturing } \\
\text { facility }\end{array}$ & 20 & 2008 \\
\hline 14. & Financing three transmission line & 64 & 2008 \\
\hline 15. & Kaladan Multimodal Transport & 100 & 2008 \\
\hline 16. & Construction of the Rhi-Tiddim road & 60 & 2010 \\
\hline 17. & Development of Transmission lines & 64 & 2010 \\
\hline 18. & $\begin{array}{l}\text { Up grading microwave link from Moreh } \\
\text { to Mandalay }\end{array}$ & 6 & 2010 \\
\hline
\end{tabular}

Source: illustrated by the author according to the data from The New Light of Myanmar Newspaper and Indian Embassy web page 
However, contrary to India's other neighbor, Myanmar had neither exported terrorists to India nor provoked political instability. Critics often argued that India had shifted its stance from earlier position of 'voicing democracy' to a pragmatic consideration. One of the arguments that brought forward was that India supported SPDC as India wanted stability in northeast region.

Many scholars had depicted that India was interested in Myanmar only for its strategic and economic compulsions. All of them did not properly mention the ties in Indo-Myanmar relation beyond these compulsions. Communal riots among border people never did happened. All the four states of northeast, Nagaland, Arunachal Pradesh, Mizoram and Manipur share common culture and linguistic asset with their cross-border neighbors in Myanmar. The old civilization $P y u$ people ${ }^{3}$ or Sriksetra people in Myanmar had a deep influence of Indian culture as every stage of their civilization there were in contact with centers of Indian civilization from Gupta ${ }^{4}$ period up to the Palas 5 . Neither Myanmar nor India annexed each other territories.

After Indian's reversed policy in 1990s, Myanmar born Indians were able to return back to invest business, a scenario which was impossible during General Ne Win's Administration. The age of globalization pushes India to commit in trade competition. But with Myanmar, India enjoys beyond trade. Culture, religion and tradition have depth of bond between people of India and Myanmar.

This paper presents overview IndoMyanmar relations, focusing not only on material forces but also on Indian attempt to bring political reform in Myanmar. The signs of democratic reforms in Myanmar

\footnotetext{
${ }^{3} \mathrm{Pyu}$ cities are situated northern Bago Region ${ }^{4}$ Gupta Period that existed from 320 -550 BCE 5Palas Empire that existed from 750-1176 BCE
}

due to the Seven Steps Road Map initiated in 2003 drove India to expedite political reform, dialogue between military regime and pro-democracy icon Aung San Su Kyi. What is more, India took a lead in effort to engage between military regime and international community. Close contact with military regime is the best way to persuade the regime to change their mind sets and urge them to speed up the process of restoration of democracy in Myanmar. India's efforts in encouragement of Myanmar's reform combined with developmental works are more helpful than international sanctions.

Myanmar is a small country compare to India in size and population. During the 1990s, realists believes that India placed economic and security interest priorities in the policy with Myanmar government. It is always arguable that the shift in India's policy and engagement with the military regime was based on security imperative and a share in gas.

Although the Indian government would like to see democracy restored in Myanmar, Indian officials are also worried that if India does not maintain good relations with the Myanmar government, Myanmar would be in the mist of isolation and the leader would never have broader outlook in international affairs.

As a result, India maintains its political and economic access to Myanmar. Beyond this political and economic access, there are some inclinations between India-Myanmar relations such as cultural, tradition, religion and language affinity.

From the empirical finding of IndoMyanmar relations from 1988 to 2010, this paper profiles India's policy towards Myanmar which reflected a mix of security, economic and moral imperatives. India has tried all its possible means and ways to call on military regime to expedite reform process, a policy differently from the West style liberal democracies but streams from 
its own 'democracy promotion' philosophy; development cooperation. The Indian have spoken out in support of the democracy but they have been reluctant to impose economic sanctions. India has played a role in fostering consensus from some countries to engage with Myanmar. After the 1616st Meeting on United Nations Human Rights Council of 2009, some countries have revealed sights of engaging with Myanmar in order to expedite reform process.

In addition, India has achieved certain context at persuading the military regime to be involved in international community. India has combined the concept of democracy with the development cooperation and engaged relations with military regime and facilitated Myanmar to restore democracy. India also has internalized the rule of good governance in Myanmar. India has supported capacity building and knowledge sharing strategies in an attempt to help Myanmar develop governance. India's efforts on knowledge sharing can be seen supporting scholarships and trainings to government and military officers, as well as civil society.

India has chosen to engage rather than adopted sanctions and pressured Myanmar because sanctions and pressures decline back to isolation and only spoiled the process of reconciliation and political reform.

India tries to strengthen bilateral relations with Myanmar government on the basis for further political reform and a peaceful transition to democracy by:

i) supporting technical and capacity building of administrative staffs as well as civil society,

ii) supporting developmental projects particularly human resources development,

iii) supporting active engagement to access UN Special Envoy to Myanmar,

iv) strengthening the governance, political, human rights and know-how skills to Myanmar governmental staffs and army officials,

v) investing to build and rebuild economic institutions as well as infrastructure and non-infrastructures in Myanmar and

vi) persuading international community to initiate comprehensive dialogue with military regime and call on to review sanction as it only make the people of Myanmar incline towards poverty.

For Indian economic investment in Myanmar, it is not a big issues that in this globalized era, every country is competing each other from economic point of view but of course not at the cost of sovereignty and integrity.

Beyond economic assumption, India and Myanmar have much in common. India's language, multi-religion and culture, in fact, influence great deals on Myanmar people. India, similarity of historical experience, cultural affinity and geographical contiguity with Myanmar, initiates step of restoring democracy in Myanmar. India's outlook towards the future of Myanmar is not only hybrid of economic and security imperatives. In fact, Myanmar is a test for how India valued on democracy. India is at the best placed to put the pressure on military regime to enable reformation to start soon.

\section{Conclusion}

The paper finding shows that India's policy towards Myanmar has prioritized three aspects; namely, economic, security and moral imperatives in Myanmar. India acts in accordance with its need and demand of the time, sometime security, and other time economy but also occasionally moral imperatives. Indian efforts to bring national reconciliation in Myanmar have received less significant. Myanmar location 
at tri-junction and a share of gas make India prioritized security and economic dimension. During the last decade, security and economic dimensions have influenced Myanmar people aspiration of democracy. Myanmar not only needs economic development but also requires human resources development, capacity building and technical know - how along with the former one. India's long determined engagement policy with Myanmar has somehow successful to call on Myanmar government to engage with international community. Decades of totalitarian governance mind sets could not be changed within days or nights. It needs year sometime decades to change. Close contact with Myanmar government brings a light of changes in decades of authoritarian influenced country.

Peaceful transition of Myanmar civilian government at the end of 2010, shows that Myanmar is trying to be on the path to fully democratic country. In this time of transition, India should put emphasize more on national reconciliation process in Myanmar.

The question of India's way of 'democracy promotion' differently from the West requires more in depth case studies and timings. For this question, it will not be enough to do case study of Indo-Myanmar relations from the view of India way of 'democracy promotion'. But one thing for sure that the significance of India's way of 'democracy promotion' is different from the West and it remains room for further study.

No one can denied the fact that globalization make the world become shrunk. Myanmar, like any other country could not be left out from this wave of globalization. The wave encourages education, information technology, human capacity building, trade and investment. The best option for India is to enhance its relations with new government to further establish solid democracy in Myanmar. It is primary essential for India to maintain peace and stability in Myanmar both for her security and economic interests. India should invest more in capacity building, needs to strengthen its democratic institutions and engagement with civil society. India needs to invest cooperation in health, education and tourism sector, too.

\section{About Author}

Htwe Hteik Tin Lwin, a Myanmar Diplomat, fulfilled the course of International Relations for Master of International Area Studies at School of Humanities and Social Sciences, University of Tsukuba, Japan. She is one of the recipients of Japanese Grant Aid for Human Resource Development Scholarship in 2012. She received her Bachelor of Art in English from Dagon University, Myanmar. She has been in diplomatic service for more than 15 years debuting from attaché. She served at Myanmar Embassy in New Delhi as Third Secretary from 2005-2008 at Political Section. She is currently serving at Myanmar Embassy in Singapore as in charge of Consular Section. She can be contacted at hht177@gmail.com.

\section{References}

Alden, Chris and Amnon Aran: Foreign Policy Analysis (London: Routledge Taylor \& Francis Group, 2012).

Bukh, Alexander: Japan's National Identity and Foreign Policy: Russia as Japan's 'other (London and New York: Taylor \& Francis Group, 2010).

Bonofer, Ashik Jacob: Recent Development in Myanmar: Implications for India (New Delhi: Ganesh \& Co. Publishers, 2009)

Blair, Alasdair and Steve Curtis: International Politics An Introductory Guide (Edinburgh: Edinburgh University Press Ltd. 2009). 
Devare, Sudhir: India and Southeast Asia: Towards Security Convergence (Singapore: Institute of Southeast Asian Studies, 2006).

Egreteau, Renaud: “India's Ambition in Burma: More Frustration than Success" (Asian Survey, Vol. 46. no.6 (November/December 2008) pp.936-957

Egreteau, Renaud: "India and Burma/Myanmar Relations: From Idealism to Realism"(New Delhi: Centre de Science Humanies, 2003).

Egreteau, Renaud: "Burmese Indians in contemporary Burma: heritage, influence and perceptions since 1988" (Asian Ethnicity, Vol.12, No.1, pp.33-54).

Egreteau, Renaud:"Conference India and Burma/Myanmar Relations: From Idealism to Realism" (New Delhi, Conference Room I, India International Centre2003).

Grare, Frederic and Amitabh Matto: India and Asean (New Delhi: Centre de Sciences Humanies, 2001).

Hadfield, Ameila Amkhan: British Foreign Policy: National Identity and Neoclassical Realism (Plymouth: Rowman and Littlefield Publisher, Inc. 2010).

Hill, Christopher: The Changing Politics of Foreign Policy (Houndmills, Basingstoke, Hampshire and New York: Palgrave Macmillan, 2003).

India - Myanmar Relations: Recent Highlights, (Yangon: Embassy of the Republic of India, July 2005).

Jackson and Sorensen: Introduction to International Relations, Second Edition (Oxford: Oxford University Press, 2003).

Jensen, Lloyd: Explaining Foreign Policy (Englewood Cliffs, N.J: PrenticeHall, 1982).

Morgenthau, Hans J: Politics among Nations: The Struggle for Power and Peace (New York NY: Alfred A. Knopf, 1948).

Malone, David M: Does the Elephant Dance? Contemporary Indian Foreign Policy (Oxford: Oxford University Press, 2011).
Maureen, Aung-Thwin \& Thant MyintU: "The Burmese Way to Socialism" (Third World Quarterly, Vol. 13, No.1, 1992, pp. 7675).

Neack, Laura: The New Foreign Policy: US and comparative foreign policy in the $21^{\text {st }}$ century (Maryland: Rowman and Littlefield Publisher, 2003).

Neck, Hey \& Haney: Foreign Policy Analysis Continuity and Change in Its Second Generation (New Jersey:Prentice-Hall, 1995).

Palmer, Glenn and T. Clifton Morgan: $A$ Theory of Foreign Policy (New Jersey: Princeton University Press, 2006).

Shambaugh, David and Michael Yahuda: International Relations of Asia (Maryland: Rowman\& Littlefield Publishers, 2008).

Stenberg, David I.: Burma/Myanmar what everyone needs to know (Madison Avenue, New York: Oxford University Press, 2010).

Soe Myint: Burma File: A Question of Democracy (Singapore: Marshall Cavendish International, 2004).

Smith, Steve and Hadfield, Amelia and Timothy Dunne: Foreign Policy: theories, actors, cases (Oxford: Oxford University Press, 2008).

Sinha, Atish and Madhup Mohta: Indian Foreign Policy: Challenges and Opportunities (New Delhi: Foreign Service Institute, 2007)

Sharma, Ashok: "India and Energy Security" (Asian Affairs, Vol. 38, No.2, 2007, pp. 158-172).

Viotti, Paul R. and Kauppi, Mark V.: International Relations Theory (Pearson Education, Inc. 2010,1999, 1993).

Waltz, Kenneth N: Theory of International politics (Boston: Addison-Wesley Publishing Company, 1979).

Webber and Smith: Foreign Policy in a Transformed World (New Jersey: Prentice Hall, 2002). 